\title{
Comparison of Different Herbal Additives on Immune Response and Growth Performance of Broiler Chickens
}

\author{
S. Masoud-Moghaddam ${ }^{a}$, J. Mehrzad ${ }^{a, *}$, A. H. Alizadeh-Ghamsari ${ }^{b}$, R. Bahari Kashani ${ }^{c}$, \& J. Saeidi ${ }^{\text {d }}$ \\ aDepartment of Biochemistry, Neyshabur Branch, Islamic Azad University, Neyshabur 9319975853, Iran \\ ${ }^{\mathrm{b}}$ Animal Science Research Institute of Iran, Agricultural Research, Education and Extension \\ Organization (AREEO), Karaj 3146618361, Iran \\ 'Department of Animal Science, Mashhad Branch, Islamic Azad University, Mashhad 9187147578, Iran \\ dDepartment of Physiology, Neyshabur Branch, Islamic Azad University, Neyshabur 9319975853, Iran \\ *Corresponding author: mehrzadjam@yahoo.com \\ (Received 24-11-2020; Revised 17-01-2021; Accepted 01-03-2021)
}

\begin{abstract}
This experiment was conducted to compare the effects of four commercial herbal additives (Noviherb $^{\circledast}$, Bioessence ${ }^{\circledast}$, Biostrong ${ }^{\oplus}$, and Novigrow $^{\circledR}$ ), and a commercial antibiotic (virginiamycin) on growth performance, carcass yield, visceral organs weight, thyroid hormones, and humoral immune responses of broiler chickens. Nine hundred day-old Ross 308 male broiler chicks were reared in littercovered floor cages and distributed into five experimental groups with six replicates of $\mathbf{3 0}$ birds. Five dietary treatments tested were diets supplemented with Noviherb $^{\oplus}$, Bioessence ${ }^{\oplus}$, Biostrong ${ }^{\circledast}$ (each of them $100 \mathrm{~g} /$ ton of diet), Novigrow ${ }^{\otimes}(1000 \mathrm{~g} / \mathrm{ton}$ of diet), and virginiamycin $(100 \mathrm{~g} / \mathrm{ton}$ of diet) as a positive control. Feed intake, body weight, mortality, feed conversion ratio, European broiler index, and feed cost per kilogram of body weight were measured during the experiment. Antibody titers against sheep red blood cells (SRBC), immunoglobulin G, immunoglobulin $M$, and plasma concentrations of thyroxine (T4) and triiodothyronine (T3) were evaluated at the age of 42 days. Then, four birds per replicate were killed to determine the relative weight of carcass and organs. The GLM procedures of SAS software and Duncan's multiple range test were applied to analyze data in a completely randomized design with five treatments and six replicates of 30 birds per each. The effects of herbal additives on productive traits feed cost per kilogram of body weight and relative weight of organs were not significant in comparison with antibiotic treatment. Dietary inclusion of Noviherb $^{\circledast}$, Biostrong ${ }^{\circledast}$, and Novigrow $^{\circledast}$ significantly $^{\circ}$ decreased feed cost per kilogram of carcass compared with Bioessence ${ }^{\circledast}$ or antibiotic treatments $(p<0.05)$. The titers of IgG in Noviherb ${ }^{\circledast}$ and virginiamycin were significantly higher $(p<0.05)$ than in Biostrong ${ }^{\circledast}$ and Novigrow ${ }^{\circledast}$ fed groups. The plasma concentration of triiodothyronine was significantly decreased

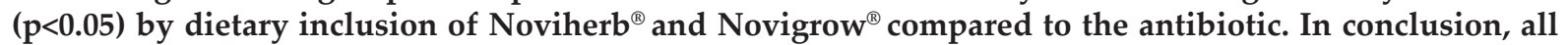
the evaluated herbal additives could act as a substitute for the growth-promoting antibiotic.
\end{abstract}

Keywords: herbal additives; broiler chicken; growth performance; immune response; virginiamycin

\section{INTRODUCTION}

Aside from the substantial role of phytogenic and medicinal compounds derived from plants in human nutrition for increasing appetite due to their functions as essence and odor, the herbal additives could also be applied in livestock feeding for animal well-being and growth improvement (Singh \& Gaikwad, 2020). Considering the prohibition of antibiotics usage in poultry diets due to the ontogeny of microbial resistance, therefore, alternative substances for growth enhancers were necessary to be made and applied (Saleh et al., 2018). Meanwhile, different kinds of bioactive additives were used to optimize the gastrointestinal integrity of birds and to promote their performances and immune functions (Adedokun \& Olojede, 2019).

Various phytogenic compounds showed pharmacological benefits and were broadly applied in human societies as a traditional medication (Yang et al., 2015). In recent years, herbal supplements are getting high priority in livestock and poultry productions, because of their wide continuum of advantageous effects, like supporting growth, production, and immunocompetence, as well as balancing the level of biochemical compounds in the circulatory system (Alagawany et al., 2015a; 2015b). Several kinds of research have described numerous biological and protecting effects of aromatic plants and phytogenic compounds, such as antioxidative, antiseptic, anti-inflammatory, immunoregulatory, and healthenhancing activities (Dhama et al., 2014; 2015).

A number of herbs containing medicinal compounds, including garlic, anise, oregano, thyme, and pepper, have been applied due to their satisfactory effects on performance, antioxidative properties, and immune response of boilers (Saleh et al., 2018). Adding a mixture of essential oils (derived from oregano, laurel, 
basil, lemon, tea, caraway, sage, and thyme) into broiler diet (100-500 g/ton) improved the weight gain, feed efficiency, and relative weight of breast and carcass (Khattak et al., 2014); meanwhile, blood biochemical parameters were not affected by the mentioned herbal mixture. Kini et al. (2016) reported that dietary inclusion of KiFAY (a commercial powder composed of garlic, onion, diatomaceous, and algal cell wall components) improved the performance of broilers with associated responses at thyroid hormones level $\left(\mathrm{T}_{3}\right.$ and $\left.\mathrm{T}_{4}\right)$.

Numerous mixtures of medicinal plants which are commercially available for the poultry industry claim to have bio-functional advantages regarding growth performance and immunocompetence. The results of recent research have shown that plant essential oils can be produced and added to the diet using micro and nanoencapsulation technologies at low and economic levels in order to allow slow release upon ingestion and have a direct effect on the target tissues (e.g., intestine) (Hosseini \& Meimandipour, 2018; Amiri et al., 2020; Lee et al., 2020). Despite examining the effects of some of these products individually, there is no enough data to compare the effects of these new (micro or nano encapsulated) forms with common forms of herbal additives. Therefore, the aim of the present study was to compare the effects of four commercial herbal additives, including nano encapsulated (Noviherb ${ }^{\circledR}$ ) and microencapsulated (Biostrong ${ }^{\circledR}$ ) forms and a commercial antibiotic on the growth performance, carcass yield, visceral organs, and immunity of broiler chickens.

\section{MATERIALS AND METHODS}

\section{Ethical Standards}

The experimental methods used in the present research were ratified by the Animal Ethics Board of Animal Science Research Institute of Iran (Approval No., 08415).

\section{Birds, Housing, and Rearing Conditions}

The location of this experiment was the Research Poultry House of Animal Science Research Institute of Iran (Karaj, Iran). Nine hundred one-day-old broiler chickens (Ross 308, with equal gender proportion) were obtained from an industrial hatchery and randomly assigned to 30-floor cages after weighing. Three square meter space was considered for each cage $\left(0.08 \mathrm{~m}^{2}\right.$ for each bird), and wood-shaving was used as litter to cover the floor of the cages. The initial temperature of the poultry house was kept at $33 \pm 2^{\circ} \mathrm{C}$ and was regularly declined $\left(2.4^{\circ} \mathrm{C}\right.$ weekly) to get a constant temperature level with the range of $21-23^{\circ} \mathrm{C}$ at the age of 28 days. Through the period of the experiment, lighting regime and relative humidity were maintained in $23: 1 \mathrm{~h}$ of light and dark cycle and 50\%-60\%, respectively.

\section{Acquisition and Compounds of the Additives}

Noviherb® was obtained from Soroush Sabz Alborz Company (Karaj, Iran). It is an herb-base addi- tive containing essential oils of oregano (Origanum vulgare), thyme (Thymus vulgaris), Ajwain (Trachyspermum ammi), and nano encapsulated form of chitosan biopolymers. Bioessence ${ }^{\circledR}$ was purchased from Tehran Mokamel Pars Company (Tehran, Iran). It is a combination of six commercial medicinal plants essences, including thyme, oregano, anise (Pimpinella anisum), fennel (Foeniculum vulgare), savory (Satureja hortensis), and dracocephalum (Dracocephalum kotschyi). Biostrong ${ }^{\circledR} 510$ was acquired from the Iranian agent of Delacon Company (Steyregg, Austria). It is a commercial feed additive comprised of a microencapsulated form of herbal essential oils (mainly thyme, star anise [Illicium verum], and quillaja bark [Quillaja saponaria]), flavorings, and carriers (Panel on Additives and Products or Substances used in Animal Feed, 2016). Novigrow ${ }^{\circledR}$ was obtained from Soroush Sabz Alborz Company (Karaj, Iran). It is a growth enhancer made from a combination of prebiotic (lactose+ yeast cell wall), organic acids (lactic acid, formic acid), some herbal compounds (turmeric [Curcuma longa], garlic [Allium satioum], and cinnamon [Cinnamomum verum] powder). Virginiamycin was purchased from the Iranian veterinary market.

\section{Diet Formulation and Experimental Design}

Before formulating the experimental diets, the chemical composition of main feed ingredients, including soybean meal and corn, were analyzed following the AOAC procedures (AOAC, 2012), and resulting data were applied to formulate the experimental diets (Tables 1 and 2). Nine hundred Ross 308 male broiler chicks on the first day of age were reared in cages with litter-covered floor and were distributed into five experimental groups with six replicates of 30 birds each. Five treatments were diets supplemented with Noviherb® (100g/ ton of diet), Bioessence ${ }^{\circledR}\left(100 \mathrm{~g} /\right.$ ton of diet), Biostrong ${ }^{\circledR}$ (100g/ton of diet), Novigrow ${ }^{\circledR}(1000 \mathrm{~g} /$ ton of diet), and virginiamycin $(100 \mathrm{~g} / \mathrm{ton}$ of diet) as a positive control. A three-phase feeding program was applied, namely, starter (days 1 to 10), grower (days 11 to 24), and finisher (days 25 to 42) with basal diets were formulated for the respective period. All diets in each phase contained similar amounts of energy and protein, according to Ross 308 recommendations (Aviagen, 2014). The birds were given feed ad libitum and free access to drinking water during the experiment.

\section{Data and Sample Collection}

Parameters regarding performance like feed intake (FI) and body weight (BW) were recorded at ages of 10, 24, and 42 days. Mortality was recorded daily in order to calculate live ability. Also, feed conversion ratio (FCR) and FI were calculated during days 1 to 10,1 to 21 , and 1 to 42 of the rearing periods. On day 42, 24 birds from each treatment (four birds per pen which had close body weight to the average of the pen) were chosen. The birds were weighed and killed after four hours of fasting; then, they were dissected, and the visceral organs were moved to measure the relative weight of carcass and organs. Weighing scale (0.001 g, model DJ-V 320A; 
Table 1. Ingredients and nutrient composition of basal diet $(\mathrm{g} / \mathrm{kg})$

\begin{tabular}{lccc}
\hline Ingredients & Starter (Days 1-10) & Grower (Days 11-24) & Finisher (Days 25-42) \\
\hline Maize $(8 \mathrm{~g} \mathrm{CP} / \mathrm{kg})$ & 526.95 & 580.75 & 624.15 \\
Soybean oil & 23.6 & 22.6 & 32.2 \\
Soybean meal $(44 \mathrm{~g} \mathrm{CP} / \mathrm{kg})$ & 331.0 & 311.0 \\
DL- Methionine $99 \%$ & 381.2 & 2.5 & 1.8 \\
L-Lysine, $\mathrm{HCl}$ & 2.5 & 1.5 & 0.5 \\
Limestone & 1.8 & 12.0 & 11.3 \\
Maize gluten & 14.0 & 30.0 & - \\
Sodium bicarbonate & 30.0 & 1.0 & 1.0 \\
Common salt & 1.0 & 3.0 & 3.0 \\
Vitamin premix & 3.0 & 2.5 & 2.5 \\
Mineral premix & 2.5 & 2.5 & 2.5 \\
Dicalcium phosphate & 2.5 & 10.6 & 10.0 \\
Phytase $(10000 \mathrm{FTU} / \mathrm{kg})$ & 10.9 & 0.05 & 0.05 \\
Nutrient composition & 0.05 & & 13.0 \\
Metabolizable energy $(\mathrm{MJ} / \mathrm{kg})$ & & 12.8 & 189.0 \\
Crude protein $(\mathrm{g} / \mathrm{kg})$ & 12.5 & 214.0 & 9.8 \\
Digestible lysine $(\mathrm{g} / \mathrm{kg})$ & 231.0 & 11.3 & 7.6 \\
Digestible methionine $+\mathrm{cystine}(\mathrm{g} / \mathrm{kg})$ & 12.7 & 9.05 & 8.5 \\
Calcium $(\mathrm{g} / \mathrm{kg})$ & 9.50 & 8.9 & 4.2 \\
Available phosphorus $(\mathrm{g} / \mathrm{kg})$ & 10.0 & 4.4 & 1.6 \\
Sodium $(\mathrm{g} / \mathrm{kg})$ & 4.5 & 1.6 & 2.2 \\
Chloride $(\mathrm{g} / \mathrm{kg})$ & 2.3 & 2.3 &
\end{tabular}

Note: ${ }^{a}=$ Vitamin premix provided following amounts per kilogram of diet: vitamin A (retinyl acetate), 15,000 IU; vitamin D3, 5,000 IU; vitamin E (dl- $\alpha$-tocopheryl acetate), $80 \mathrm{mg}$; vitamin $\mathrm{K}, 5 \mathrm{mg}$; thiamin, $3 \mathrm{mg}$; riboflavin, $10 \mathrm{mg}$; pyridoxine, $5 \mathrm{mg}$; vitamin B12, $0.02 \mathrm{mg}$; niacin, $70 \mathrm{mg}$; choline chloride, $350 \mathrm{mg}$; folic acid, $2 \mathrm{mg}$; biotin, $0.4 \mathrm{mg}$; and pantothenic acid, $20 \mathrm{mg}$.

$\mathrm{b}=$ Mineral premix provided following amounts per kilogram of diet: Mn (manganese sulphate), $100 \mathrm{mg}$; Zn (zinc sulphate), 65 mg; Cu (copper sulphate), $5 \mathrm{mg}$; Se (sodium selenite), $0.22 \mathrm{mg}$ and I (calcium iodate), $0.5 \mathrm{mg}$.

$\mathrm{c}=$ Determined using individual feed analysis results.

AND Weighing, China) was used to measure the weight of carcass, legs, breast, and organ weights. At the end of the experiment, the European broiler index (EBI) was calculated based on the formula of Marcu et al. ( 2013) as follows: $\mathrm{EBI}=[$ livability $(\%) \times$ average daily gain $(\mathrm{g})] /$ [feed conversion ratio $(\mathrm{g} / \mathrm{g}) \times 10$ ].

Total feed cost was measured by multiplying total feed consumed by the price per kilogram of each dietary treatment. Feed cost per kilogram of body weight was calculated as total feed cost divided by live body weight at the end of the experiment (day 42). Feed cost per kilogram of the carcass was calculated as total feed cost divided by carcass weight at the end of the experiment.

At the ages of 28 and 35 days, one mL of 5\% suspension of sheep red blood cells (SRBC) was intravenously administrated to four birds per replicate. Blood samples were collected one week after the second administration (Peterson et al., 1999). Blood samples were centrifuged at $3000 \times \mathrm{g}$ for 15 minutes, and the prepared sera were stored at $-20^{\circ} \mathrm{C}$ for subsequent analyses. The inactivation of each serum sample was performed at $56^{\circ} \mathrm{C}$ for $30 \mathrm{~min}$, and then sera were analyzed for total titer of anti-SRBC antibodies according to the method of Moslehi et al. (2019). Briefly, each inactivated serum was titrated in order to evaluate the total and mercaptoethanol (ME)-resistant (IgG) anti-SRBC antibody titers. Titers of ME-sensitive (IgM) antibodies were gained by subtracting IgG antibodies level (titer) from total antibodies. All data for antibody titer were reported in terms of $\log _{2}$.

At 42 days of age, blood samples of four birds in each replication were taken via wing vein. Blood samples were subsequently centrifuged $(1,000 \times \mathrm{g}$ for 15 $\mathrm{min}$ ) to obtain plasma and retained at $-20^{\circ} \mathrm{C}$ for further analysis (Kamely et al., 2015). Plasma concentrations of thyroxine $\left(\mathrm{T}_{4}\right)$ and triiodothyronine $\left(\mathrm{T}_{3}\right)$ were measured by the commercial laboratory kit (Pishtaz Teb, Tehran, Iran) through the enzyme-linked immunosorbent assay.

\section{Statistical Analysis}

The GLM procedures of SAS 9.1 software (SAS, 2003) were applied to analyze data in a completely randomized design. Percentage data with high enough CV value were transformed to arcsine before analysis. The pen of birds functioned as the experimental unit. When treatment indicated significant effect, it was continued to Duncan's multiple range test for the comparison of the means at $5 \%$ probability.

\section{RESULTS}

\section{Growth Performance}

The results of herbal additive effects on the performance of broiler chickens are summarized in Table 2. As 
shown in this table, the effects of four herbal additives on BW, FI, FCR, liveability, EBI, and feed cost per kilogram of BW were not different among all treatments. At the age of 42 days, FCR in birds that received herbal additive treatments was numerically lower, but it was not statistically different than those given antibiotics.

\section{Carcass Characteristics}

The effects of herbal additives on carcass yield and internal organ weights of broiler chickens in comparison to antibiotic treatment are presented in Table 3 . The carcass yield and relative weights of breast, leg, heart, liver, gizzard, and intestine were not affected by dietary treatments. However, dietary inclusion of Noviherb ${ }^{\circledR}$, Biostrong ${ }^{\circledR}$, and Novigrow ${ }^{\circledR}$ were significantly decreased $(p<0.05)$ feed cost per kilogram of carcass compared with Bioessence ${ }^{\circledR}$ or antibiotic treatments.

\section{Humoral Immunity}

The effects of dietary treatments on humoral immune responses of broiler chicks on day 42 are indicated in Table 4. Regarding SRBC and IgM, no significant difference was observed among dietary treatments; however, the titer of IgG was affected by the inclusion of additives $(p<0.05)$. The titers of IgG in groups fed with Noviherb $^{\circledR}$, virginiamycin, and Bioessence ${ }^{\circledR}$ were significantly higher $(\mathrm{p}<0.05)$ than those receiving Biostrong ${ }^{\circledR}$.

\section{Thyroid Hormones}

The results of the herbal additive effects on thyroid hormone concentrations of 42 days old broiler chickens in comparison to the antibiotic are displayed in Table 5. As shown in this table, the concentration of $\mathrm{T}_{3}$ and the ratio of $\mathrm{T}_{3}$ to $\mathrm{T}_{4}$ were significantly $(\mathrm{p}<0.05)$ influenced by

Table 2. Performance of broiler chickens fed diets supplemented by herbal additives

\begin{tabular}{|c|c|c|c|c|c|c|c|}
\hline \multirow{2}{*}{ Variables } & \multicolumn{5}{|c|}{ Herbal additive $^{1}$} & \multirow{2}{*}{ SEM } & \multirow{2}{*}{ P-value } \\
\hline & Virginiamycin $^{2}$ & Noviherb ${ }^{\circledR}$ & Bioessence ${ }^{\circledR}$ & Biostrong ${ }^{\circledR}$ & Novigrow ${ }^{\circledR}$ & & \\
\hline \multicolumn{8}{|l|}{ BW (g) } \\
\hline day 10 & 255.96 & 254.29 & 250.75 & 249.61 & 252.24 & 1.12 & 0.108 \\
\hline day 24 & 1083.14 & 1061.78 & 1076.38 & 1061.84 & 1075.61 & 5.78 & 0.453 \\
\hline day 42 & 2746.16 & 2735.48 & 2771.91 & 2763.59 & 2803.24 & 13.36 & 0.692 \\
\hline \multicolumn{8}{|l|}{ FI (g/ bird) } \\
\hline days $1-10$ & 240.6 & 249.2 & 248.2 & 259.6 & 249.7 & 0.28 & 0.584 \\
\hline days $1-24$ & 1462.2 & 1401.5 & 1387.6 & 1422.9 & 1409.0 & 0.79 & 0.641 \\
\hline days $1-42$ & 4750.8 & 4623.0 & 4740.0 & 4615.2 & 4737.5 & 1.62 & 0.285 \\
\hline \multicolumn{8}{|l|}{ FCR ( $\mathrm{g}$ feed/g gain) } \\
\hline days $1-10$ & 0.94 & 0.98 & 0.99 & 1.04 & 0.99 & 0.02 & 0.375 \\
\hline days $1-24$ & 1.35 & 1.32 & 1.30 & 1.34 & 1.31 & 0.04 & 0.850 \\
\hline days $1-42$ & 1.73 & 1.69 & 1.71 & 1.67 & 1.69 & 0.02 & 0.567 \\
\hline Live ability (days 1-42),\% & 98.57 & 98.90 & 94.76 & 99.05 & 95.71 & 1.45 & 0.184 \\
\hline EBI (d 1-42) & 372.5 & 381.1 & 365.7 & 391.3 & 378.0 & 3.36 & 0.492 \\
\hline Feed cost (Rials)/BW (kg) & 72940 & 69840 & 71710 & 70600 & 69680 & 380.9 & 0.120 \\
\hline
\end{tabular}

Note: $\mathrm{BW}=$ body weight; $\mathrm{FI}=$ feed intake; $\mathrm{FCR}=$ feed conversion ratio; $\mathrm{EBI}=$ European broiler index; $\mathrm{SEM}=\mathrm{Pooled}$ standard error of the mean. ${ }^{1}=\mathrm{Each}$ herbal additive was supplemented at the level of $100 \mathrm{~g} /$ ton of diet, except Novigrow ${ }^{\circledR}$, which was supplemented at the level of $1000 \mathrm{~g} / \mathrm{ton}$; $2=$ Virginiamycin was included as a positive control and supplemented at the level of $100 \mathrm{~g} / \mathrm{ton}$ diet.

Table 3. Carcass yield and organs relative weight ( $\mathrm{g} / 100 \mathrm{~g}$ of live body weight) of broiler chickens fed diets supplemented by herbal additives on day 42

\begin{tabular}{lccccccc}
\hline \multirow{2}{*}{$\begin{array}{l}\text { Variables } \\
\text { (g/100 g of live body weight) }\end{array}$} & \multicolumn{3}{c}{ Herbal additive $^{1}$} & \multirow{2}{*}{ SEM } & P-value \\
\cline { 2 - 6 } Carcass yield & Virginiamycin $^{2}$ & Noviherb® & Bioessence® & Biostrong® & Novigrow & & \\
Breast & 73.64 & 74.83 & 73.34 & 75.90 & 74.39 & 0.580 & 0.850 \\
Legs & 23.29 & 23.02 & 22.29 & 22.95 & 24.04 & 0.349 & 0.770 \\
Heart & 20.29 & 20.96 & 19.39 & 20.09 & 19.13 & 0.240 & 0.110 \\
Liver & 0.520 & 0.592 & 0.509 & 0.592 & 0.549 & 0.019 & 0.230 \\
Gizzard & 2.572 & 2.493 & 2.321 & 2.552 & 2.541 & 0.040 & 0.670 \\
Intestine & 3.150 & 3.110 & 3.270 & 3.451 & 3.131 & 0.074 & 0.760 \\
Feed cost (Rials)/carcass (kg) & 7.54 & 7.79 & 8.18 & 7.67 & 7.51 & 1.009 & 0.757 \\
\hline
\end{tabular}

Note: ${ }^{a-b}$ Means in the same row with different superscripts differ significantly $(p<0.05)$. SEM= Pooled standard error of the mean. ${ }^{1}=$ Each herbal additive was supplemented at the level of $100 \mathrm{~g} /$ ton of diet, except Novigrow ${ }^{\circledR}$, which was supplemented at the level of $1000 \mathrm{~g} / \mathrm{ton} ;{ }^{2}=\mathrm{Virginiamycin}$ was included as a positive control and supplemented at the level of $100 \mathrm{~g} /$ ton diet. 
Table 4. Humoral immune responses of broiler chickens fed diets supplemented by herbal additives on day 42

\begin{tabular}{lccccccc}
\hline \multirow{2}{*}{ Variables $^{1}$} & \multicolumn{3}{c}{ Herbal additive $^{2}$} & \multirow{2}{*}{ SEM } & \multirow{2}{*}{ P-value } \\
\cline { 2 - 6 } & Virginiamycin $^{3}$ & Noviherb ${ }^{\circledR}$ & Bioessence ${ }^{\circledR}$ & Biostrong $^{\circledR}$ & Novigrow ${ }^{\circledR}$ & & \\
\hline Sheep red blood cell (SRBC) & 7.67 & 8.00 & 7.67 & 7.00 & 7.67 & 0.116 & 0.190 \\
Immunoglobulin G (IgG) & $5.33^{\text {ab }}$ & $5.67^{\mathrm{a}}$ & $5.00^{\mathrm{abc}}$ & $4.00^{\mathrm{d}}$ & $4.60^{\mathrm{cd}}$ & 0.124 & 0.001 \\
Immunoglobulin M (IgM) & 2.33 & 2.33 & 2.67 & 3.00 & 3.06 & 0.116 & 0.311 \\
\hline
\end{tabular}

Note: ${ }^{a-d}$ Means in the same row with different superscripts differ significantly $(p<0.05)$. SEM= Pooled standard error of the mean. ${ }^{1=}$ The data for antibody titer was reported in terms of $\log 2{ }^{2}=$ Each herbal additive was supplemented at the level of $100 \mathrm{~g} / \mathrm{ton}$ of diet, except Novigrow ${ }^{\circledR}$ which was supplemented at the level of $1000 \mathrm{~g} / \mathrm{ton} ;{ }^{3}=$ Virginiamycin was included as a positive control and supplemented at the level of $100 \mathrm{~g} / \mathrm{ton}$ diet.

Table 5. Concentration of plasma thyroid hormones of broiler chickens fed diets supplemented by herbal additives on day 42

\begin{tabular}{|c|c|c|c|c|c|c|c|}
\hline \multirow{2}{*}{ Variables } & \multicolumn{5}{|c|}{ Herbal additive $^{1}$} & \multirow{2}{*}{ SEM } & \multirow{2}{*}{ P-value } \\
\hline & Virginiamycin $^{2}$ & Noviherb ${ }^{\circledR}$ & Bioessence ${ }^{\circledR}$ & Biostrong ${ }^{\circledR}$ & Novigrow ${ }^{\circledR}$ & & \\
\hline Triiodothyronine (T3) (ng/mL) & $3.44^{\mathrm{a}}$ & $2.12^{\mathrm{b}}$ & $2.92^{\mathrm{ab}}$ & $3.18^{\mathrm{ab}}$ & $2.28^{\mathrm{b}}$ & 0.153 & 0.033 \\
\hline Thyroxine (T4) (ng/mL) & 3.67 & 3.67 & 5.00 & 5.17 & 3.33 & 0.230 & 0.066 \\
\hline $\mathrm{T} 3 / \mathrm{T} 4$ & $0.940^{\mathrm{a}}$ & $0.587^{b}$ & $0.633^{b}$ & $0.617^{b}$ & $0.677^{b}$ & 0.027 & 0.001 \\
\hline
\end{tabular}

Note: ${ }^{a-b}$ Means in the same row with different superscripts differ significantly $(\mathrm{p}<0.05)$. SEM= Pooled standard error of the mean. ${ }^{1=}$ Each herbal additive was supplemented at the level of $100 \mathrm{~g} /$ ton of diet, except Novigrow ${ }^{\circledR}$, which was supplemented at the level of $1000 \mathrm{~g} / \mathrm{ton} ;{ }^{2}=\mathrm{Virginiamycin}$ was included as a positive control and supplemented at the level of $100 \mathrm{~g} /$ ton diet.

dietary treatments. The concentration of $\mathrm{T}_{3}$ significantly $(\mathrm{p}<0.05)$ decreased in Noviherb ${ }^{\circledR}$ and Novigrow ${ }^{\circledR}$ treatments compared to the antibiotic-receiving group. In addition, the ratio of $\mathrm{T}_{3}$ to $\mathrm{T}_{4}$ was significantly lower in all herbal additive groups than antibiotic-treated birds $(\mathrm{p}<0.05)$.

\section{DISCUSSION}

The results of this research showed that the effects of four evaluated herbal additives on productive traits (BW, FI, FCR, liveability, EBI, and feed cost per kilogram of $\mathrm{BW}$ ) were not significantly different in comparison with antibiotic treatment, suggesting that the use of antibiotics as a growth promoter can be replaced by any of these additives.

The dietary inclusion of antibiotics is an old used strategy in order to promote the performance of broiler chicks (Hussein et al., 2020). Subtherapeutic, in-feed antibiotics could improve body weight gain up to $8 \%$ and decrease the feed conversion ratio (feed intake/body weight gain) up to $5 \%$, both compared with an antibiotic-free diet during 1-42 days of age (Gadde et al., 2018). These researchers also reported that dietary supplementation of virginiamycin, increased chicken body weight gain by $10.1 \%$ between days 1 and 21 of age compared with control groups. Furthermore, a noticeable correlation has been reported between the inclusion level of avilamycin in the diet and the reduction in the mortality rate (Paradis et al., 2016; Mwangi et al., 2018). Since the forbidding of such antibiotic growth promoters, alternative approaches have been offered, such as the dietary addition of organic acids, prebiotics, probiotics, and Phyto biotics (Mora et al., 2020).

Phyto biotics have been reported to possess capabilities such as the improvement of health and performance (Diaz-Sanchez et al., 2015; Clavijo-López \& VivesFlorez, 2018). Plant-based essential oils (individually or combined together) have been applied as food and feed additives to boost the immune responses of humans and animals against different pathogens (Bajpai et al., 2012; Ali, 2014; Hassan et al., 2016; Hussein et al., 2020).

As previously mentioned, Noviherb ${ }^{\circledR}$ contains essential oils of thyme, oregano, Ajwain, and nanoencapsulated form of chitosan biopolymers. The earlier studies have shown that thyme oil had main chemical compounds including carvacrol, linalool, geraniol, $\gamma$-terpineol, and thymol (Boruga et al., 2014), while oregano essential oils contain $\beta$-fenchyl alcohol, carvacrol, $\gamma$-terpinene, thymol (Teixeira et al., 2013), and ajwain essential oils include thymol along with $\alpha$ - and $\gamma$-terpinene, $\alpha$ - and $\beta$-pinene, and p-cymene (Chahal et al., 2017). Noviherb ${ }^{\circledR}$ also contains chitosan which has antibacterial properties (Goy et al., 2016, Meimandipour et al., 2017). Antimicrobial properties of Thyme, Oregano, and ajwain essential oils were also documented by other researchers (Boruga et al., 2014; Teixeira et al., 2013; Hassanshahian et al., 2014). So, it can be concluded that this growth enhancer $\left(\right.$ Noviherb $\left.^{\circledast}\right)$ may be a good substitute for the antibiotic.

Carvacrol and thymol, the two basically similar main components of oregano and thyme, as well as an essential oil, were found to have a synergistic effect on the physiological state of broilers (Hashemipour et al., 2013). Moreover, p-cymene found in ajwain and savory, a biological precursor of carvacrol, was found to have a higher favorite for liposomal membranes, thereby producing more expansion. By this mechanism, cymene maybe enables carvacrol to be more easily transported into the cell so that a synergistic effect is attained when the two are used together (Zeng et al., 2015).

Bioessence ${ }^{\circledast}$ contains six medicinal plants essences including thyme, oregano, anise, fennel, savory, and dracocephalum. Some of the major chemical compositions found in anise seed include p-anisaldehyde, estragole, anise alcohol, limonene, anethole, and 
pinene, but anethole is a main component (Sun et al., 2019). Estragole and Trans-anethole were found to be the main components of fennel seeds essential oils (Diao et al., 2014). According to the results of Miladi et al. (2013), the essential oils of savory were dominated by $\gamma$-terpinene, mono-terpenic hydrocarbons p-cymene, and carvacrol. Farimani et al. (2017) noted that the major compound in the essential oils of dracocephalum is limonene. These researchers also showed antibacterial properties of this plant. The antimicrobial activity of savory is originated from carvacrol, thymol, and other monoterpenoid hydrocarbons (Miladi et al., 2013). A number of studies indicated the synergistic antibacterial effects of essential oils containing anethole, estragole, limonene, and carvacrol in combination together (Bassole \& Juliani, 2012; Auezova et al., 2020). So, we can conclude that Bioessence ${ }^{\circledR}$ is established upon compounds having an antimicrobial activity that can act as an alternative for antibiotics.

Biostrong ${ }^{\circledR} 510$ is comprised of a microencapsulated form of herbal essential oils (mainly thyme, star anise, and quillaja bark). Compounds like $\alpha$ - and $\beta$-pinene, $\alpha$ - and $\gamma$-terpineol, limonene, linalool, estragole, and trans-anethole present in the essential oils of star anise are shown to possess various antibacterial activities (Aly et al., 2016; Luis et al., 2019). Supplementing Biostrong in diet improved growth rate, meat production, and feed efficiency of Cobb 508 broiler chickens (Lavrentyev et al., 2019). Therefore, this product can also be used as an alternative for the growth-promoting antibiotic.

Combinations of certain essential oils (estragole, limonene, anethole, thymol, and carvacrol) exhibited a synergic effect against foodborne pathogens and also a vital reduction in their individual minimum inhibitory concentrations (MIC) against foodborne pathogens. Thyme essential oils presented the lowest singular MIC, but its usage in the mixture declined the MIC of the other essential oils (Garcia-Diez et al., 2017). The capability of Bioessence ${ }^{\circledR}$ and Biostrong ${ }^{\circledR} 510$ for the substitution of antibiotics could be related to synergism between their individual bioactive components and the aforementioned mechanism.

Novigrow $^{\circledR}$ is made based on lactose, yeast cell wall, lactic acid, formic acid, and some herbal compounds like turmeric, garlic, and cinnamon powder. Vicente et al. (2007) applied lactose as a prebiotic and showed that dietary addition of products containing lactose and Lactobacillus spp. had positive effects on feed conversion ratio and body weight gain of turkeys infected with Salmonella. Yalcin et al. (2014) reported augmented humoral immune response, improved growth performance, and reduced abdominal fat by dietary inclusion of yeast cell wall. Based on the results of Fascina et al. (2012), organic acids have growth-promoting properties and can be used as substitutes of antibiotics. Navidshad et al. (2018) indicated that chemical components of garlic (including allicin) have beneficial effects for animals, including growth-enhancing and antimicrobial effects. El-Hack et al. (2020) reviewed the antimicrobial properties of cinnamon and concluded that it could be applied as a replacement for antibiotics for more well-being, financial, and environmental aspects of poultry production. In conclusion, we can express that Novigrow $^{\circledR}$ also possesses antibiotic-like properties.

Carcass yield and relative percentage of breast, leg, heart, liver, gizzard, and intestine were not influenced by dietary treatments. It has been hypothesized that dietary antibiotic supplementation reduces the relative weight of the intestine (Gunal et al., 2006). In the current study, there was no major difference between herbal additives and antibiotics regarding carcass yield and organ relative weight, which may imply antibiotic-like properties of applied herbal additives. Additionally, the lower feed cost per kilogram of the carcass in birds that received Noviherb $\AA$, Biostrong $\AA$, and Novigrow $\AA$ in comparison to the antibiotic may imply the financial benefit of using herbal additives for broiler producers (El-Hack et al., 2020).

In the present study, the IgG titers in Noviherb ${ }^{{ }_{-}}$ received group were similar to that given virginiamycin and were higher than birds receiving Novigrow ${ }^{\circledR}$ or Biostrong ${ }^{\circledR}$. Yakhkeshi et al. (2011) reported that application of Primalac ${ }^{\circledR}$ and virginiamycin resulted in the maximum and minimum antibody titers against SRBC, respectively. Increased immune responses have been noted by using herbal extracts in diets (Mathivanan \& Kalaiasari, 2007) and are in agreement with the data obtained in this study. According to Cook \& Samman (1996), herbal extracts augment immune response by promoting vitamin $\mathrm{C}$ action. For instance, Sangrovit $\AA$ is a herbal additive known to possess immunomodulatory properties (Karimi et al., 2014). It has been noted that Sangrovit@ motivates the activity of phagocyte and therefore endorses defensive responses against diseases in broilers (El-Sheikh et al., 2018).

In our study, the concentration of $\mathrm{T}_{3}$ was reduced in birds with dietary inclusion of Noviherb $^{\circledR}$ and Novigrow $^{\circledR}$ compared to the antibiotic. Also, the $T_{3}$ to $T_{4}$ ratio was lowered in all the birds fed with herbal additive than the antibiotic-receiving group. In the study of Sadeghi \& Moghaddam (2018), the concentration of thyroid hormones in broiler chicks that received medicinal plants had a tendency to increase at the age of 42 days. This result was in contrast with the present study. On the other hand, the reducing effect of some flavonoids on thyroid function is reported in rats by Chandra \& De (2010). These researchers indicated that catechin prevents the activity of thyroperoxidase and decreases the serum levels of $\mathrm{T}_{3}$ and $\mathrm{T}_{4}$.

\section{CONCLUSION}

In conclusion, dietary inclusion of the evaluated herbal additives can be considered as substitution alternatives to growth-promoting antibiotic. The IgG titers in birds receiving Noviherb ${ }^{\circledR}$ indicate the same value as that given virginiamycin and are higher than that fed with Biostrong ${ }^{\circledR}$ or Novigrow ${ }^{\circledR}$. Feed cost per kilogram of carcass is decreased in birds consumed Noviherb $\AA$, Biostrong ${ }^{\circledR}$, and Novigrow ${ }^{\circledR}$ in comparison to that received growth promoter antibiotic. 


\section{CONFLICT OF INTEREST}

No potential conflict of interest was stated by the authors.

\section{ACKNOWLEDGEMENT}

The authors would like to thank the Soroush Sabz Alborz Company, Iran, for the financial support of this research.

\section{REFERENCES}

Adedokun, S. A. \& O. C. Olojede. 2019. Optimizing gastrointestinal integrity in poultry: the role of nutrients and feed additives. Front. Vet. Sci. 5:348. https://doi.org/10.3389/ fvets.2018.00348

Akeel, R. A., Y. Al-Sheikh, A. Mateen, R. Syed, K. Janardhan \& V. C. Gupta. 2014. Evaluation of antibacterial activity of crude protein extracts from seeds of six different medical plants against standard bacterial strains. Saudi J. Biol. Sci. 21:147-151. https://doi.org/10.1016/j.sjbs.2013.09.003

Alagawany, M. M., M. R. Farag \& K. Dhama. 2015a. Nutritional and biological effects of turmeric (Curcuma longa) supplementation on performance, serum biochemical parameters and oxidative status of broiler chicks exposed to endosulfan in the diets. Asian J. Anim. Vet. Adv. 10:86-96. https:// doi.org/10.3923/ajava.2015.86.96

Alagawany, M. M., M. R. Farag, K. Dhama, M. E. Abd El-Hack, R. Tiwari \& G. M. Alam. 2015b. Mechanisms and beneficial applications of resveratrol as feed additive in animal and poultry nutrition: A review. Int. J. Pharmacol. 11:213221. https://doi.org/10.3923/ijp.2015.213.221

Auezova, L., A. Najjar, M. Kfoury, S. Fourmentin \& H. GreigeGerges. 2020. Antibacterial activity of free or encapsulated selected phenylpropanoids against Escherichia coli and Staphylococcus epidermidis. J. Appl. Microbiol. 128:710-720. https://doi.org/10.1111/jam.14516

Ali, A. H. H. 2014. Productive performance and immune response of broiler chicks as affected by dietary marjoram leaves powder. Egypt. Poult. Sci. J. 34:57-70. https://doi. org/10.21608/epsj.2014.5306

Aly, S. E., B. A. Sabry, M. S. Shaheen \& A. S. Hathout. 2016. Assessment of antimycotoxigenic and antioxidant activity of star anise (Illicium verum) in vitro. J. Saudi Soc. Agric. Sci. 15:20-27. https://doi.org/10.1016/j.jssas.2014.05.003

Amiri, N., M.Afsharmanesh, M.Salarmoini, A. Meimandipour, S. A. Hosseini \& H. Ebrahimnejad. 2020. Effects of nanoencapsulated cumin essential oil as an alternative to the antibiotic growth promoter in broiler diets. J. Appl. Poult. Res. 29:875-885. https://doi.org/10.1016/j.japr.2020.08.004

AOAC. 2012. Official Methods of Analysis of AOAC International. 19 $9^{\text {th }}$ ed. Assoc. Off. Anal. Chem., Gaithersburg, Maryland.

Aviagen. 2014. Ross 308: Broiler Nutrition Specifications. http://en.aviagen.com/assets/Tech_Center/Ross_Broiler/ Ross308BroilerNutritionSpecs2014-EN.pdf. [12 April 2016].

Bajpai, V. K., K. -H. Baek \& S. C. Baek. 2012. Control of Salmonella in foods by using essential oils: A review. Food Res. Int. 45:722-734. https://doi.org/10.1016/j. foodres.2011.04.052

Bassole, I. H. N. \& H. R. Juliani. 2012. Essential oils in combination and their antimicrobial properties. Molecules 17:39894006. https://doi.org/10.3390/molecules17043989

Boruga, O., C. Jianu, C. Misca, I. Golet, A. T. Gruia \& F. G. Horhat. 2014. Thymus vulgaris essential oil: Chemical composition and antimicrobial activity. J. Med. Life. 7:56-60.

Chahal, K. K., K. Dhaiwal, A. Kumar, D. Kataria \& N. Singla. 2017. Chemical composition of Trachyspermum ammi L. and its biological properties: A review. J. Pharmacogn. Phytochem. 6:131-140.

Chandra, A. K. \& N. De. 2010. Goitrogenic/antithyroidal potential of green tea extract in relation to catechin in rats. Food Chem. Toxicol. 48:2304-2311. https://doi.org/10.1016/j. fct.2010.05.064

Clavijo-López V. \& M. J. Vives-Florez. 2018. The gastrointestinal microbiome and its association with the control of pathogens in broiler chicken production: A review Poult. Sci. 97:1006-1021. https://doi.org/10.3382/ps/pex359

Cook, N. C. \& S. Samman. 1996. Flavonoids-chemistry, metabolism, cardioprotective effects, and dietary sources. J. Nutr. Biochem. 7:66-76. https://doi.org/10.1016/ S0955-2863(95)00168-9

Dhama, K., S. Chakraborty, R. Tiwari, A. K. Verma, M. Saminathan, Y. S. Amarpal-Malik, Z. Nikousefat, M. Javdani \& R. U. Khan. 2014. A concept paper on novel technologies boosting production and safeguarding health of humans and animals. Res. Opin. Anim. Vet. Sci. 4:353-370.

Dhama, K., S. K. Latheef, S. Mani, H. A. Samad, K. Karthik, R. Tiwari, R. Khan, M. Alagawany, M. Farag, G. Alam, V. Laudadio \& V. Tufarelli. 2015. Multiple beneficial applications and modes of action of herbs in poultry health and production-a review. Int. J. Pharmacol. 11:152-176. https:// doi.org/10.3923/ijp.2015.152.176

Diao, W. R., Hu, Q. P., Zhang, H, \& J. G. Xu. 2014. Chemical composition, antibacterial activity and mechanism of action of essential oil from seeds of fennel (Foeniculum vulgare Mill.). Food Control 35:109-116. https://doi.org/10.1016/j. foodcont.2013.06.056

Diaz-Sanchez, S., D. D'Souza, D. Biswas \& I. Hanning. 2015. Botanical alternatives to antibiotics for use in organic poultry production. Poult. Sci. 94:1419-1430. https://doi. org/10.3382/ps/pev014

El-Hack, M. E. A., M. Alagawany, A. M. E. Abdel-Moneim, N. G. Mohammed, A. F. Khafaga, M. Bin-Jumah, S. I. Othman, A. A. Allam \& S. S. Elnesr. 2020. Cinnamon (Cinnamomum zeylanicum) oil as a potential alternative to antibiotics in poultry. Antibiotics. 9:210. https://doi. org/10.3390/antibiotics9050210

El-Sheikh, S. M., M. H. Khairy, N. Z. Eleiwa, O. E. Abdalla \& A. G. A. El-Monsef. 2018. Effect of sanguinarine phytobiotic, sodium butyrate compared to ampicillin on controlling necrotic enteritis in broiler chickens. Slov. Vet. Res. 55 (Suppl. 20):405-414.

Farimani, M. M., F. Mirzania, A. Sonboli \& F. M. Moghaddam. 2017. Chemical composition and antibacterial activity of Dracocephalum kotschyi essential oil obtained by microwave extraction and hydrodistillation. Int. J. Food Prop. 20:306315. https://doi.org/10.1080/10942912.2017.1295987

Fascina, V. B., J. R. Sartori, E. Gonzales, F. Barros De Carvalho, I. M. G. Pereira De Souza, G. V. Polycarpo, A. C. Stradiotti \& V. C. Pelicia. 2012. Phytogenic additives and organic acids in broiler chicken diets. R. Bras. Zootec. 41:2189-2197. https://doi.org/10.1590/S1516-35982012001000008

Gadde, U.D., S. Oh, H. S. Lillehoj \& E. P. Lillehoj. 2018. Antibiotic growth promoters virginiamycin and bacitracin methylene disalicylate alter the chicken intestinal metabolome. Sci. Rep. 8:3592. https://doi.org/10.1038/ s41598-018-22004-6

Garcia-Dieza, J., J. Alheiroa, A. L. Pintoa, V. Falcob, M. J. Fraquezac \& L. Patarata. 2017. Synergistic activity of essential oils from herbs and spices used on meat products against foodborne pathogens. Nat. Prod. Commun. 
12:281-286. https://doi.org/10.1177/1934578X1701200236

Goy, R. C., S. T. B. Morais \& O. B. G. Assis. 2016. Evaluation of the antimicrobial activity of chitosan and its quaternized derivative on $E$. coli and S. aureus growth. Rev. Bras. Farmacogn. 26:122-127. https://doi.org/10.1016/j. bjp.2015.09.010

Gunal, M., G. Yayli, O. Kaya, N. Karahan \& O. Sulak. 2006. The effects of antibiotic growth promoter, probiotic or organic acid supplementation on performance, intestinal microflora and tissue of broilers. Int. J. Poult. Sci. 5:149-155. https:// doi.org/10.3923/ijps.2006.149.155

Hashemipour, H., H. Kermanshahi, A. Golian \& T. Veldkamp. 2013. Effect of thymol and carvacrol feed supplementation on performance, antioxidant enzyme activities, fatty acid composition, digestive enzyme activities, and immune response in broiler chickens. Poult. Sci. 92:2059- 2069. https:// doi.org/10.3382/ps.2012-02685

Hassan, W., S. Gul-Rehman, H. Noreen, Z. Shah, I. Mohammadzai \& B. Zaman. 2016. Chemical composition, essential oil characterization and antimicrobial activity of Carum copticum. Vitam. Miner. 5:1-5. https://doi. org/10.4172/2376-1318.1000139

Hassanshahian, M., Z. Bayat, S. Saeidi \& Y. Shiri. 2014. Antimicrobial activity of Trachyspermum ammi essential oil against human bacterial. Int. J. Adv. Biol. Biomed. Res. 2:18-24.

Hosseini, S. \& A. Meimandipour. 2018. Feeding broilers with thyme essential oil loaded in chitosan nano-particles: An efficient strategy for successful delivery. Br. Poult. Sci. 59: 669-678. https://doi.org/10.1080/00071668.2018.1521511

Hussein, E. O. S., S. H. Ahmed, A. M. Abudabos, M. R. Aljumaah, M. M. Alkhlulaifi, M. A. Nassan, G. M. Suliman, M. A. E. Naiel \& A. A. Swelum. 2020. Effect of antibiotic, phytobiotic and probiotic supplementation on growth, blood indices and intestine health in broiler chicks challenged with Clostridium perfringens. Animals. 10:507. https://doi.org/10.3390/ani10030507

Kamely, M., M. A. Karimi Torshizi \& S. Rahimi. 2015. Incidence of ascites syndrome and related hematological response in short-term feed-restricted broilers raised at low ambient temperature. Poult. Sci. 94:2247-2256. https:// doi.org/10.3382/ps/pev197

Karimi, M., F. Foroudi \& M. R. Abedini. 2014. Effect of Sangrovit ${ }^{\circledR}$ on performance and morphology of small intestine and immune response of broilers. Biosci. Biotechnol. Res. Asia. 11:855-861. https://doi.org/10.13005/bbra/1348

Khattak, F., A. Ronchi, P. Castelli \& N. Sparks. 2014. Effects of natural blend of essential oil on growth performance, blood biochemistry, cecal morphology, and carcass quality of broiler chickens. Poult. Sci. 93:132-137. https://doi. org/10.3382/ps.2013-03387

Kini, A., C. Fernandes \& D. Suryawanshi. 2016. Effect of KiFAY on Performance, Insulin-like Growth Factor-1, and Thyroid Hormones in Broilers. Asian-Australas. J. Anim. Sci. 29:1451-1457. https://doi.org/10.5713/ajas.16.0188

Lavrentyev, A.Y., A. I. Nikolaeva , N. V. Evdokimov , V. G. Semenov , V. S. Sherne, E. Y. Nemtseva , N. V. Danilova, N. S. Petrov \& G. M. Toboyev. 2019. The Efficiency of The Use of "Biostrong 510" Additive in The Technology of broiler chicken meat production. IOP Conf. Ser.: Earth Environ. Sci. 346: 012053. [20 February 2020]. https://doi. org/10.1088/1755-1315/346/1/012053

Lee, J. W., D. H. Kim, Y. B. Kim, S. B. Jeong, S. T. Oh, S. Y. Cho \& K. W. Lee. 2020. Dietary encapsulated essential oils improve production performance of coccidiosis-vaccinechallenged broiler chickens. Animals 10:481. https://doi. org/10.3390/ani10030481

Leeson, S. 2007. Balancing science versus societal issues in poultry nutrition. CAB Rev. 2:1-5. https://doi.org/10.1079/ PAVSNNR20072071

Luis, A., S. Sousa, J. Wackerlig, D. Dobusch, A. P. Duarte, L. Pereira \& F. Domingues. 2019. Star anise (Illicium verum Hook. F.) essential oil: Antioxidant properties and antibacterial activity against Acinetobacter baumannii. Flavour Frag. J. 34: 260-270. https://doi.org/10.1002/ffj.3498

Marcu, A., I. Vacaru-Opris, G. Dumitrescu, L. PetculescuCiochina, A. Marcu, M. Nicula, I. Pet, D. Dronca, B. Kelciov \& C. Maris. 2013. The influence of genetics on economic efficiency of broiler chickens growth. J. Anim. Sci. Biotechnol. 46:339-346.

Mathivanan, R. \& K. Kalaiarasi. 2007. Panchagavya and Andrographis panculata as alternatives to antibiotic growth promoters on hematological, serum biochemical parameters and immune status of broilers. J. Poult. Sci. 44:198-204. https://doi.org/10.2141/jpsa.44.198

Meimandipour, A., A. N. Emamzadeh, \& A. Soleimani. 2017. Effects of nanoencapsulated aloevera, dill and nettle root extract as feed antibiotic substitutes in broiler chickens. Arch. Anim. Breed. 60:1-7. https://doi.org/10.5194/ aab-60-1-2017

Miladi, H., R. Ben Slama, D. Mili, S. Zouari, A. Bakhrouf \& E. Ammar. 2013. Chemical composition and cytotoxic and antioxidant activities of Satureja montana L. essential oil and its antibacterial potential against Salmonella Spp. strains. J. Chem. 2013:1-9. https://doi.org/10.1155/2013/275698

Mora, Z. V.-D., M. E. Macías-Rodríguez, J. Arratia-Quijada, Y. S. Gonzalez-Torres, K. Nuño \& A. Villarruel-López. 2020. Clostridium perfringens as foodborne pathogen in broiler production: Pathophysiology and potential strategies for controlling necrotic enteritis. Animals 10:1718. https://doi. org/10.3390/ani10091718

Moslehi, H., B. Navidshad, S. D. Sharifi \& F. M. Aghjegheshlagh. 2019. Effects of selenium and flaxseed on selenium content and antioxidant properties of eggs and immune response in hens. S. Afr. J. Anim. Sci. 49:770780. https://doi.org/10.4314/sajas.v49i4.19

Mwangi, S., J. Timmons, S. Fitz-Coy \& S. Parveen. 2018. Characterization of Clostridium perfringens recovered from broiler chicken affected by necrotic enteritis. Poult. Sci. 98:128-135. https://doi.org/10.3382/ps/pey332

Navidshad, B., B. Darabighane \& M. Malecky. 2018. Garlic: An alternative to antibiotics in poultry production, a review. Iran. J. Appl. Anim. Sci. 8:9-17.

Panel on Additives and Products or Substances Used in Animal Feed. 2016. Safety and efficacy of BIOSTRONG® 510 (essential oil of thyme and star anise) for chickens and minor avian species for fattening and rearing to point of lay. EFSA J. 14:4351. https://doi.org/10.2903/j.efsa.2016.4351

Paradis, M. A., E. McMillan, R. Bagg, G. Vessie, A. Zocche \& M. Thompson. 2016. Efficacy of avilamycin for the prevention of necrotic enteritis caused by a pathogenic strain of Clostridium perfringens in broiler chickens. Avian Pathol. 45:365-369. https://doi.org/10.1080/03079457.2016.1165793

Peterson, A. L., M. A. Qureshi, P. R. Ferket \& J. C. Fuller Jr. 1999. Enhancement of cellular and humoral immunity in young broilers by the dietary supplementation of $\beta$-hydroxy$\beta$-methylbutyrate. Immunopharmacol. Immunotoxicol. 21:307-330. https://doi.org/10.3109/08923979909052765

Sadeghi, A. A. \& M. Moghaddam. 2018. The effects of turmeric, cinnamon, ginger and garlic powder nutrition on antioxidant enzymes' status and hormones involved in energy metabolism of broilers during heat stress. Iran. J. Appl. Anim. Sci. 8:125-130.

Saleh, A. A., T. A. Ebeid \& A. M. Abudabos. 2018. Effect of dietary phytogenics (herbal mixture) supplementation on growth performance, nutrient utilization, antioxidative 
properties, and immune response in broilers. Environ. Sci. Pollut. Res. 25:14606-14613. https://doi.org/10.1007/ s11356-018-1685-z

SAS. 2003. User's guide: Statistics Version 9.1. Statistical Analysis Software Institute, Cary, North Carolina.

Singh J. \& D. S. Gaikwad. 2020. Phytogenic feed additives in animal nutrition. In: Singh, J. \& Yadav, A. (Eds). Natural Bioactive Products in Sustainable Agriculture. Springer, Singapore. p. 273-289. https://doi. org/10.1007/978-981-15-3024-1_13

Sun, W., M. H. Shahrajabian, Q. Cheng \& S. Sabatini. 2019. Anise (Pimpinella anisum L.), a dominant spice and traditional medicinal herb for both food and medicinal purposes. Cogent Biol. 5:1-25. https://doi.org/10.1080/2331202 5.2019.1673688

Teixeira, B., A. Marques, C. Ramos, C. Serrano, O. Matos, N. R. Neng, J. M. F. Nogueira, J. A. Saraiva \& M. L. Nunes. 2013. Chemical composition and bioactivity of different oregano (Origanum vulgare) extracts and essential oil. J. Sci. Food Agric. 93: 2707-2714. https://doi.org/10.1002/jsfa.6089

Vicente, J., A. Wolfenden, A. Torres-Rodriguez, S. Higgins, G. Tellez \& B. Hargis. 2007. Effect of a Lactobacillus speciesbased probiotic and dietary lactose prebiotic on turkey poultry performance with or without Salmonella enteritidis challenge. J. Appl. Poult. Res. 16: 361-364. https://doi. org/10.1093/japr/16.3.361

Yakhkeshi, S., S. Rahimi \& K. Gharib Naseri. 2011. The effects of comparison of herbal extracts, antibiotics, probiotics and organic acid on serum lipids, immune response, GIT microbial population, intestinal morphology and performance of broilers. J. Med. Plant. 10:80-95.

Yalcin, S., S. Yalcin, H. Eser, A. Sahin, S. S. Yalcin \& S. Gucer. 2014. Effects of dietary yeast cell wall supplementation on performance, on carcass characteristics, antibody production and histopathological changes in broilers. Kafkas Univ. Vet. Fak. Derg. 20:757-764. https://doi.org/10.9775/ kvfd.2014.11088

Yang, C., M. A. Chowdhury, Y. Huo \& J. Gong. 2015. Phytogenic compounds as alternatives to in-feed antibiotics: Potentials and challenges in application. Pathogens. 4:137-156. https://doi.org/10.3390/pathogens4010137

Zeng, Z., S. Zhang, H. Wang \& X. Piao. 2015. Essential oil and aromatic plants as feed additives in non-ruminant nutrition: A review. J. Anim. Sci. Biotechnol. 6:1-10. https://doi. org/10.1186/s40104-015-0004-5 